Lim Andy (Orcid ID: 0000-0002-2522-3927)

Lim Alvin (Orcid ID: 0000-0002-0403-2355)

Title:

\title{
Choosing the discount rate in an economic analysis
}

Letter to the Editor

\section{Authors:}

Dr Andy Lim

Emergency Physician | Adjunct Lecturer

MBBS BMedSci FACEM AFIML CCPU MCHSM AMA(M)

\author{
Mr Alvin Lim \\ Physiotherapist | Medical Student \\ BPhysio AMA(M)
}

\section{Author's Contribution:}

Andy Lim was involved in the conception and design of the work. Andy and Alvin were involved in the drafting, revising, and final approval.

\section{Addresses:}

Holmesglen Emergency Department P/L

490 South Road Moorabbin

95679000

Monash Medical Centre

246 Clayton Road Clayton

95946666

University of Queensland

This is the author manuscript accepted for publication and has undergone full peer review but has not been through the copyediting, typesetting, pagination and proofreading process, which may lead to differences between this version and the Version of Record. Please cite this article as doi: $10.1111 / 1742-6723.13357$

This article is protected by copyright. All rights reserved. 
St Lucia, Brisbane, Queensland

\section{Correspondence address:}

Dr Andy Lim

Andy.lim2@monashhealth.org

Monash Medical Centre

246 Clayton Road Clayton

95946666

\section{Word Count:}

503

Dear Editor,

In reference to the recent work on understanding economic evaluation alongside emergency medicine research by Singh et $\mathrm{al}^{1}$, we would like to draw attention to the selection of the discount rate when performing an economic analysis. This choice has implications in that a figure in the lower ranges may overestimate the value of an outcome or the cost of an intervention or project. A higher rate may result in less promising results and may even be enough to send a potential capital investment's Net Present Value into the negative.

There are three different options to selecting an appropriate discount rate, depending on what the aim of the calculations are.

National guidelines

This article is protected by copyright. All rights reserved. 
When performing a healthcare economics study within Australia, one method for choosing the rate would be to follow existing guidelines, namely that of the Pharmaceutical Benefits Advisory Committee (PBAC) and Medicare Services Advisory Committee ${ }^{2}$. The PBAC requires that costs and benefits incurred or received in the future are discounted to the present value at a uniform, annual rate of $5 \%^{2}$. This approach is simple, allowing for standardised comparison between multiple propositions.

\section{Weighted Average Cost of Capital (WACC)}

When preparing to submit a healthcare business case for a project or major capital expenditure for an organisation, the WACC can be used. Using results from a health economics study will not necessarily be translatable directly to an organisation as each hospital may face a cost of equity higher than $5 \%$, reducing the estimated value added that a healthcare economics study may suggest. The WACC is the after-tax weighted average required return for all types of securities issued by a company $^{3}$. This can be calculated as follows:

$$
W A C C=\left(\frac{D}{D+E}\right)(1-T) r_{d}+\left(\frac{E}{D+E}\right) r_{e}
$$

Where $\mathrm{D}=$ debt, $\mathrm{E}=$ equity, $\mathrm{T}=$ marginal tax rate, $\mathrm{r}_{\mathrm{d}}=$ rate of return on debt, and $\mathrm{r}_{\mathrm{e}}=$ rate of return on equity ${ }^{3}$. For example, if the hospital capital structure is $\$ 100 \mathrm{M}$ equity at a $15 \%$ required return and $\$ 100 \mathrm{M}$ debt at a 5\% interest rate, and the marginal tax rate is 30\%, the WACC for that particular hospital would be as follows:

$$
W A C C=\left(\frac{100}{100+100}\right)(1-0.3) \times 0.05+\left(\frac{100}{100+100}\right) \times 0.15=0.075=7.5 \%
$$

This approach is especially relevant to services in the private sector, where shareholder return needs to be taken into account. 


\section{Pre-determined company discount rate}

Fortunately, the hospital finance department may choose a pre-determined company-wide WACC for budget submissions to avoid needing to calculate this each time. For instance, at one of the author's institutions, the company-wide discount rate is $6.25 \%$ for all projects. This allows hospital administration to have control over the threshold for project acceptance by setting the desired rate with the option of building in a margin of error.

Taking into account the time value of money is important in any economic analysis, whether it be the economic impact of a medical intervention or when valuing the profitability of a capital investment. The selection of an appropriate discounting rate has a marked effect on the final result of an analysis, so it is important to ensure a reasonable choice depending on the type of analysis. 


\section{References}

1. Singh S, Cheek JA, Babl FE, Hoch JS. Review article: A primer for clinical researchers in the emergency department: Part X. Understanding economic evaluation alongside emergency medicine research. Emerg Med Australas. doi:10.1111/1742-6723.13320

2. Australian Government Department of Health. Guidelines for preparing a submission to the Pharmaceutical Benefits Advisory Committee Version 5.0 September 2016. Canberra, A.C.T: Dept. of Health and Ageing; 2016.

3. Graham JR, Adam C, Gunasingham B, Smart SB. Introduction to corporate finance. Second Asia-Pacific edition. ed: Cengage Learning; 2017. 
Title:

\title{
Choosing the discount rate in an economic analysis
}

Letter to the Editor

Authors:

Dr Andy Lim

Emergency Physician | Adjunct Lecturer

MBBS BMedSci FACEM AFIML CCPU MCHSM AMA(M)

\author{
Mr Alvin Lim \\ Physiotherapist | Medical Student \\ BPhysio AMA(M)
}

\section{Author's Contribution:}

Andy Lim was involved in the conception and design of the work. Andy and Alvin were involved in the drafting, revising, and final approval.

\section{Addresses:}

Holmesglen Emergency Department P/L

490 South Road Moorabbin

95679000

Monash Medical Centre

246 Clayton Road Clayton

95946666

University of Queensland

St Lucia, Brisbane, Queensland

\section{Correspondence address:}

Dr Andy Lim

Andy.lim2@monashhealth.org

This article is protected by copyright. All rights reserved. 
Monash Medical Centre

246 Clayton Road Clayton

95946666

\section{Word Count:}

503

This article is protected by copyright. All rights reserved. 


\section{University Library}

\section{- M M N E R VA A gateway to Melbourne's research publications}

Minerva Access is the Institutional Repository of The University of Melbourne

Author/s:

Senz, A;llarda, E;Klim, S;Kelly, A-M

Title:

Introducing routine risk assessment for occupational violence and aggression in the emergency department

Date:

2019-07-25

\section{Citation:}

Senz, A., Ilarda, E., Klim, S. \& Kelly, A. -M. (2019). Introducing routine risk assessment for occupational violence and aggression in the emergency department. EMERGENCY MEDICINE AUSTRALASIA, 31 (5), pp.897-898. https://doi.org/10.1111/1742-6723.13358.

Persistent Link:

http://hdl.handle.net/11343/286204 